\title{
CHALLENGES FOR SUSTAINABLE TOURISM USING BARCELONA AS A CASE STUDY
}

\author{
Dr. Anett Tözsér \\ Research Institute for National Strategy, researcher, anett.tozser@nski.gov.hu
}

DOI: $10.15170 /$ TVT.2021.06.02.08

\begin{abstract}
The study focuses on the context of sustainable tourism through a literature review examining the phenomenon of overtourism, which had become common prior to the current global pandemic and the efforts made to adjust for it. The global coronavirus pandemic has drastically impacted tourism, endangering the livelihoods of many, while also bringing temporary cessation of overtourism. However, the question is: to what extent and how the world is preparing and dealing with bringing tourism back to pre-pandemic level and if that level of tourism can be sustainable. The study presents the phenomenon of overtourism and uses Barcelona as a case study of a city that implemented changes to tackle the issues of overtourism. It also points out the extent of imbalance created by overtourism on the living conditions of the local population and what measures the city government finally took to address excessive tourism prior to the pandemic.
\end{abstract}

Keywords: sustainable tourism, overtourism, pandemia, Barcelona

\begin{abstract}
Absztrakt
A tanulmány a fenntartható turizmus összefüggésére koncentrál egy a túlturizmus jelenségét amely általánossá vált a jelenlegi világszintű pandémiát megelőzően - valamint az ahhoz való alkalmazkodás nehézségeit, körülíró szakirodalmi áttekintésen keresztül. A világszintü koronavírus járvány drasztikus hatással volt a turizmusra, veszélyeztetve sokak megélhetését, miközben a túlturizmus átmeneti megszünést hozta.

Mindemellett a kérdés: milyen mértékben és hogyan készül a világ a turizmus visszahozatalára a pandémia előtti szintre és ez a szint fenntartható lesz-e? A tanulmány bemutatja a túlturizmus jelenségét és Barcelonát veszi esettanulmánynak, mint olyan város, amely lépéseket tett a túlturizmus következményeinek leküzdésére. Szintén rámutat a túlturizmus következtében a helyi lakosság életkörülményeiben bekövetkezett egyensúlytalanság mértékére, illetve azokra az intézkedésekre, amelyeket a pandémia előtt végül meghozott a helyi kormányzat, a túlfejlett turizmus okozta problémák kezelésére.
\end{abstract}

Keywords: fenntartható turizmus, túlturizmus, pandémia, Barcelona 


\section{Introduction}

The goal of this study is to evaluate whether sustainable tourism principals can help to overcome the negative impacts of overtourism.

The study examines the relationships between the phenomena of sustainable tourism and overtourism. Sustainable tourism is not opposed to growth, but it recognizes that there are limits to growth. Sustainable tourism focuses on ensuring the quality of life for local residents, the quality of natural and cultural resources. In contrast, overtourism is a phenomenon in which previously attractive destinations become overcrowded, and tourism exacerbates the problems of already congested urban (transport, supply etc.) systems, causing significant conflicts between locals and tourists. Prior to the pandemic, popular destinations, including the city of Barcelona examined in this study, were severely affected by overtourism. In this situation, the city has sought to limit the number and movement of tourists by various means, such as managing the activities of tourists, limiting the number of tourists, and establishing a dialogue between tourism organizations, local authorities and residents. The phenomenon of overtourism was put to an end by the pandemic situation, which minimized tourist movement, creating a critical situation for those employed in tourism and hospitality sectors.

The documents I reviewed, revealed that economic development should not focus only on economic considerations, but that economic development should also aim to improve people's quality of life. Sustainable development sets the boundaries for growth and, beyond economic development, focuses on ensuring the well-being of people and the quality of natural and cultural resources. The literary study also suggests that the phenomenon of overtourism ignores the principles of sustainable tourism. In recent decades, we have seen that travel has become increasingly affordable, which has encouraged tourist to travel more and cities to invite more tourists. However, this has led to a number of contradictions. Although the growing number of visitors is favorable for tourism, the deterioration of infrastructure, more difficult access to services, increasing cost of housing and the transformation of the cityscape have led to a significant deterioration in the quality of life of tourist destinations. The recommendations of the sustainable tourism principals remain only recommendations, as only few countries or cities have government programs for the management and administration of tourism. Through literature research, I found a good example in Barcelona (which is an example of the controversial relationship between tourists and the population in recent decades), and the measures the city has taken to address overtourism. Although the pandemic has made tourism impossible, it can fundamentally provide the opportunity for a promising future with sustainable tourism for all involved.

\section{Interpretation of sustainable tourism}

Based on the literature, the essence of sustainable tourism could be summarized in such a way that the interests of the three actors (tourism industry, local population, environment) are equally important, but the balance never tilts in favor of one over another. Overall, the development of tourism can be sustained in a destination even if no factor stays in the background compared to the other, and if the interests and needs of all actors prevail in a balanced way (DÁVID - BAROS 2007). I am convinced that the economic benefits of tourism, defined as the successful sale of destinations in the tourism market, can only be achieved and maintained in the long term if the human, natural and cultural resources that form the foundation of tourism development are maintained.

The Brundtland Report and the World Conference on Environment and Development in Rio de Janeiro were instrumental in developing the concept and principles of sustainability. The principles and concept of sustainability are defined by the UN World Commission on Environment and Development, the so-called The Brundtland Commission's report „Our Common Future” (UNDESA 1987). 
On this basis, sustainable development ensures that the needs of the present are met without making it impossible to meet the needs of future generations. According to the report, quantitative and qualitative growth are only viable together, meaning that the economy can only grow together with the protection of the environment. The three pillars of sustainable development are the environment, the economy, and society, which need to be taken into account together in the planning process.

Following the Brundtland Commission's report, the Recommendation of the Agenda 21 Program (UNCED 1992), adopted at the 1992 World Conference on Environment and Development in Rio de Janeiro, focused on the appropriate use and protection of the natural and cultural environment. According to this, natural and cultural resources must be used in a way that preserves ecological processes, biodiversity and life support systems. The recommendation does not oppose economic growth, as long as it does not harm the environment. The report calls for a balance of interests in terms of development, utilization of environmental resources and protection of the environment. Although Agenda 21 provided a narrower scope for societal findings than the Brundtand report, it can be said that in this document, too, sustainability presupposes the simultaneous pursuit of the interests of the economy, society and the environment. Although the reports did not cover the subject of tourism, they set out a number of principles that should be considered for sustainable tourism, such as improving people's quality of life, integrated development, providing a national framework for nature conservation and enabling the community to take care of their own environment.

The concept of sustainable tourism has developed in parallel with the concept and principles of sustainability. Due to the global impact of tourism, the issue of tourism development already needed to be addressed. Inappropriate development of tourism can damage the natural and cultural environment on which the desire to visit a destination is based (PUCZKÓ - RÁTZ 2005). The concept of sustainable tourism first appeared in John Krippendorf's book The Holiday Makers (1987). In his interpretation, ,alternative tourism" has emerged as the opposite of mass tourism that results in negative effects. The literature on naming the new trend is not uniform. According to Krippendorf, sustainable tourism can be called ,gentle tourism”, ,alternative tourism”, „green tourism” or „ecotourism” (TASNÁDI 2002). Unlike other types of tourism products, ecotourism involves smaller groups and is even characterized by an educational explanation of the experience and its conscious interpretation (UNWTO 2002, MICHALKÓ 2003).

However, sustainable tourism cannot be equated with eco-tourism or nature tourism, because sustainable tourism is primarily a development principle, while eco-tourism or nature tourism is a product type. Tourism is a factor and a component of sustainable development, just as ecotourism is a type of tourism. However, „Article 3 of the Global Code of Ethics for Tourism” also points out that the principles of sustainable tourism can best be achieved through eco-tourism or nature tourism (UNWTO 2002, MICHALKÓ 2003).

There have been several definitions of sustainable tourism in recent decades, but the UNWTO definition (UNWTO 2000) is one of the best-known interpretations. The definition takes into account the interests of all actors in tourism. Sustainable tourism development meets the needs of current tourists and host areas on the one hand, and protects and increases opportunities for the future on the other hand. It is envisioned to enable the management of resources in such a way that humanity can meet its economic, social, aesthetic needs, while preserving basic ecological processes, biodiversity, life-sustaining systems, and the cultural integrity of different people and groups. 
In the development of the concept of sustainable tourism, the following approach emerged in the domestic and foreign literature. The concept of sustainability is ,holistic”, involving the protection of natural and cultural resources, the improvement of the quality of life of the local population and the provision of long-term economic benefits. The principles of sustainable tourism development are set out in the following international documents:

- Manila Declaration 1981 (UNWTO 1980);

- Hague Declaration 1989 (UNWTO - IPU 1989);

- Agenda 21 on Travel and Tourism 1995 (UNWTO - WTTC - EC 1995);

- Global Code of Ethics 1999 (UNWTO 1999);

- Osaka Millennium Declaration 2001 (UNWTO 2001);

- Recommendation of the World Conference on Tourism 2002 (UNWTO 2002);

- Recommendation of the World Conference on Ecotourism 2002 (QUEBEC DECLARATION ON ECOTOURISM 2002).

The content of the above documents is based on the Brundtland Report and, although differing in the main emphases, all include the role of the three pillars of sustainable development (natural environment, economy, society). The international documents and research in relation to sustainable tourism, the following main principles have been defined in general (eg. BURTON 1995, MOWFORTH - MUNT 1998, PUCZKÓ - RÁTZ 2005, DÁVID - BAROS 2007, DÁVID - SZÜCS 2008, HOLDEN 2016 etc.):

- ensuring the growth of the tourism economy,

- safeguarding the economic and social interests of local society and increasing its quality of life,

- protecting the natural and cultural environment,

- ensuring tourist satisfaction,

- developing social ,rules of conduct” (for both the population and the tourist),

- implementating long-term, integrated conscious planning and development (taking into account the interests of the above groups),

- involving the local population in the development process,

- developing the capacity of the local population to maintain traditional knowledge,

- building an effective partnership in planning and implementation,

- monitoring of developments continously, conducting impact assessments,

- encouraging the development of alternative tourism.

Based on the above principles, sustainable tourism is a balance of interests between the three „pillars” (tourism industry, local population and environment). This can guarantee the improvement of the quality of life as the main goal of ethical, sustainable tourism development. These principles suggest that tourism is looking for an environment that ensures continuous guest traffic. It has the necessary resources, the right incentives, a skilled workforce etc. to do this. Environmental interests include the protection of the natural and cultural environment, the conscious use of resources in planning and implementation, and the consideration of the load capacity of the area. The population wants to live in a location that provides them with suitable living conditions (work, education, leisure opportunities, health services etc.), that protects the heritage of the location and that enables it to participate in the social life of the community (UNWTO 2000).

I also agree with these principals, because we must act responsibly in reducing economic inequalities in economic development, to protect the condition of our culture and environment. Economic development must aim to improve people's quality of life, while also taking into account human needs.

I consider the holistic approach of sustainable tourism to be the right direction for tourism, because it does not oppose growth, but at the same time recognizes that there are limits to growth. The approach focuses on ensuring the quality of human life, and the quality of natural and cultural resources. 
These factors are the most important foundations and goals of sustainable tourism development. In the course of tourism activity, it is necessary to minimize the negative effects of tourism and to use the revenues to improve the living conditions of the local community.

Documents dealing with sustainable tourism (eg UNWTO 1980, UNWTO - IPU 1989, UNWTO - WTTC - EC 1995, UNWTO 1999, UNWTO 2001) and researchers (eg LENGYEL 2004, PUCZKÓ - RÁTZ 2005) emphasize that all the objectives of sustainable tourism can be achieved if tourism is consciously planned and if it does not develop spontaneously. Planning is really effective if it takes into account the perspectives of all tourism actors and tourism-related sectors. I believe that greater involvement of the public in the planning process is needed to a greater extent than at present. First, because the population is most in possession of knowledge of the resources in the area. Second, improvements are effective if they are made cooperatively with the participation of the population, considering the effects on them. Thirdly, because the positive effects of tourism on the population have a positive effect on the population's attachment to the area and the population's attitude towards further tourism developments.

\section{From mass tourism to the crisis caused by the coronavirus}

Tourism was growing industry prior to the pandemic. According to the UNWTO Tourism Barometer, the number of international tourists in the world has increased by $6 \%$ in 2018 (UNWTO 2019). Additionally, there was opportunity to improve the quality of the visits.

Prior to the coronavirus pandemic, a great many European cities struggled with the phenomenon of overtourism. Despite declaring 2017 the International Year for the Development of Sustainable Tourism, the World Council on Travel and Tourism found that few countries have government programs to manage and administer tourism.

Overtourism means an excessive increase in the number of visitors in a given reception area, which results in residents suffering from continuous and/or seasonal visitor peaks and which permanently changes their lifestyle, access to services and general well-being. Overtourism damages the landscape, places a heavy burden on infrastructure, displaces residents from the real estate market, increases the cost of living, causes pollution, thus damaging the authentic nature and special atmosphere of destinations (CLAUDIO et al. 2018, UNWTO 2018, INTERNATIONAL YEAR OF SUSTAINABLE TOURISM FOR DEVELOPMENT 2017).

Travel has become more affordable than before, resulting in higher number of visitors to popular cities. Cities are now forced to address the growing number of tourists and the resulting deterioration of infrastructure by trying to limit the number of visitors. A further contradiction is that while the growing number of tourists has favored tourism and hospitality, the rising house prices and the increased cost of living resulted in lower disposable income for the local population. Lower disposable income means that local residents end up staying home, because they cannot afford to eat out in restaurants or go shopping in those tourist destinations (UNWTO 2018).

Prior to the pandemic, more and more destinations, such as Venice, Barcelona, Palma de Mallorca, Paris, Dubrovnik, Kyoto, Berlin, Bali, Reykjavik, were suffering from „overtourism”. Barcelona, for example, had 30 million guest nights in 2017, while its population is 1,625,137 (CLAUDIO et al. 2018).

Thus, it can be seen that the phenomenon of overtourism can be exemplified by the negative effects of tourism. The nature of the impact of tourism depends on the extent of development to accommodate tourists. International and domestic experience shows that spontaneous, uncontrolled mass tourism usually accompanies the proliferation of negative effects. Examples of negative effects are congestion of infrastructure, the commercialization of culture, the destruction and pollution of the natural environment, and rising house prices. Conscious development of sustainable tourism is a method for reducing these effects and strengthening the positive effects. 
All this is basically the task of the public sector, as the private sector is expected to operate profitably and fairly, but it lacks the interest or incentives to perform non-profit tasks (because it is basically short-term and profit-oriented) (LENGYEL 2004, PUCZKÓ - RÁTZ 2005).

The consequences of overtourism led to the „tourism phobia" that Manuel Delgado first wrote about more than a decade ago. This includes the dislike of tourists (but not tourism) and goes hand in hand with distrust of them. More and more civil initiatives have been launched to protect southern Europe, such as the Co-operation for Sustainable Tourism or the Anti-Tourism Network of Southern European Cities. These organizations have tried to combat the phenomenon of overtourism and its negative effects on the population (CLAUDIO et al. 2018).

Many good examples of tackling the overtourism phenomenon have emerged in recent years, but some of these also seemed to be more ad hoc solutions, ignoring disciplined planning and the sustainable tourism principles. These solutions include the introduction of new tax rules, the payment of fines related to new local regulations, and the reduction of marketing activities. As a result of new regulations, fewer tourists were attracted to large organized travel groups, instead visiting as individuals or smaller family groups spending more money with less negative impacts (CLAUDIO et al. 2018).

UNWTO (2018) emphasized the introduction of travel restrictions that served the protection of locals rather than visitors. Such bans have been introduced in Barcelona and Venice, among others, where tourism has put great pressure on the local economy and infrastructure. Bans were introduced when restrictions did not address effectively the large number of tourists and the negative impacts on a given destination.

Overall, the phenomenon of overtourism is growing as a result of unrestrained mobility and increased wealth. At the same time, there is an urgent need to rethink how destinations can evolve so that tourists respect the rights of the local population (CLAUDIO et al. 2018).

The overtourism phenomenon was eliminated by the global coronavirus pandemic, which caused a drastic decline in tourist traffic temporarily deferring the needs above.

\section{Measures and recommendations for protection against coronavirus}

Prior to the coronavirus pandemic, tourism was a sector whose growth was well above average in GDP, yet at the same time constantly overloading environment, local infrastructure and unable to absorb the ever-increasing mass interest in travel.

However, during the epidemic situation, international tourism traffic to Europe decreased by at least 70\% in OECD countries (MEGAN 2020). The worldwide spread of the coronavirus pandemic has shown how fragile tourism is. The difficulties previously arising from growth in tourism have been replaced by new challenges to rebuilding the sector. The recovery of the travel and tourism sector requires a solid platform that provides necessary funding sources, greater protection of sociocultural and natural values, and the achievement of environmental and strategic sustainability goals. In a wide-ranging study by EplerWood International (MEGAN 2020), several governments agreed that there should be a change of direction in tourism development. Future growth must be balanced growth that provides well-funded systems at the destination level. The primary means of correcting the imbalances are to create a financial base, to develop infrastructure and to put the local population on a firmer platform for sustainable recovery.

The European Commission initiated the development of a European Marshall Plan on 21 April 2020. The Commission established an objective to create a plan covering the travel and tourism, environment and digital sectors. Tourist destinations really need targeted reconstruction funds that help preserve vital tourism products. Development funds would support the sites that are most vulnerable to tourism. This new support system would finance reconstruction and rehabilitation, largely based on sustainability goals. It also spreads the risk and allows a wide range of people in need to be helped quickly. This form of support could best be described as a global fund with a global focus. 
The ECM study (2020) explained that gradual recovery after the pandemic will occur in early 2021. Until then, bilateral travel agreements can be concluded, but all international tourism may be subject to country-specific restrictions, and travelers may be subject to quarantine rules. Restrictions mostly affect only the groups most exposed to infections. After April 2021, travel restrictions may be lifted except for limited geographic areas that will remain subject to restrictions. According to the model developed by the organization, the time interval for response and recovery will vary from country to country.

The study makes a proposal for the adaptation and protection of the destination. According to ECM, congestion management solutions need to be implemented in the destination locations, such as the use of digital technology. Priority will be given to improving air quality, regulating the operation of cramped business premises, ensuring the quality of life of the local population, encouraging entrepreneurs to use underutilized properties, regulating visitor flows and encouraging routes and programs that allow and ensure a balanced flow of guests.

Public expectations can be met by loyalty programs, the provision of discounts, flexibility and the possibility of re-booking in the event of unexpected cancellations, transparency of health measures, high-quality cleaning and maintenance of public spaces and parks among other things. The expectations of industry professionals can be met by contactless customer relationship solutions (vending machines, voice recognition, applications), personal addressing and building trust of customers, virtual attendance at events, online ticket purchases, providing online tours, telecommuting opportunities.

\section{Barcelona as a case study}

Prior to the coronavirus pandemic, UNWTO (2018) brought attention to the case of Barcelona. Barcelona is among the destinations where overtourism has been a major cause for concern. The unresolved nature of excessive tourism would have had an impact on city life for years to come.

BALLESTER (2018) explained that overcrowding was the biggest problem in Barcelona and there was no strategic planning to address the situation. There was also conflict between tourists and residents.

Barcelona has been cited as an example of a successful tourist destination since the 1992 Olympic Games. The positive effects of the Olympics were, among other things, the restructuring of the range of municipal services and the implementation of urban planning projects and high-quality public spaces for recreation. The facades of public areas and buildings were renewed, and hotel improvements were made. However, they have also quite transformed the cityscape and the impact of tourism. International events introduced new service providers to the local tourism industry. The Olympic Games defined the city's offerings for the next 20 years, including Barcelona's theme road, which offers shopping opportunities, and a „festival city” image that made the city exemplary internationally. Increasingly, tourism has become the engine of the economy in the Catalan capital. Looking back to the early 1980 s, the number of visitors to the city was a lot smaller. It received 800,000 international tourists during this period, and yet it was not one of the top 20 most visited cities in Europe. However, the number of guest beds in the city increased from 25,000 in 1992 to more than 70,000 in 2015. According to some studies (BARCELONA TURISME 2017 IN BALLESTER 2018), tourism accounted for more than $15 \%$ of the gross domestic product (GDP) of the city. It has created more than 200,000 jobs with direct and indirect economic effects and generated more than $€ 10$ billion in revenue per year. The development of tourism and services was at the heart of all urban development projects. The city was the 4th most visited city in Europe in 2012 according to the Top City Destination Ranking and was the 3rd in 2015 according to the MasterCard program, behind London and Paris. In addition, according to various world rankings, Barcelona was between 8th and 16th place in 2015 among worldwide destinations. Cruise tourism is a significant comparative advantage for Barcelona over other major European cities. 
More than 2.68 million cruise passengers visited Barcelona in 2017, making it the number one cruise port in Europe, ahead of Venice. It remains behind Florida's three main ports, to become the world's 4th largest cruise port. In addition, according to a 2017 municipal study (BARCELONA TURISME 2017 IN BALLESTER 2018), cruise tourism brought in more than $€ 475$ million annually, which is a crucial element in the economy of the Catalan capital. It is worth mentioning that the acquisition of famous soccer player Lionel Messi by FC Barcelona has contributed to interest in the city by sport fans. The growth of tourism is also well illustrated by the total number of guests in the city's hotels between 1990 and 2019, according to which the number of tourists increased fivefold (from 1.73 to 9.47 million) during the period considered (DIAZ 2020).

Growing international tourism has also transformed the system of housing rental and the housing market. At the same time, the concern of locals has also increased, as the old cityscape has changed significantly due to the increase in the number of foreign tourists. Since Barcelona became one of the five most visited European cities (after London, Paris, Rome and Prague), it paid a high price due to the negative effects of the crowds of tourists, especially young people and young couples. For the past five years, residents of Barcelona have been protesting regularly and demanding a solution from the municipality to the problems caused by tourists. Tourists were unaware of the „,rules of conduct" and stayed in unregulated apartments.

The constant change in the cityscape, the seven thousand illegal renters in Barcelona, and the fact that the number of tourists in some districts exceeded the local population, and at the same time the price of apartments increased drastically, affected the population more and more. After the Olympics, wealthy investors also appeared in the city, offering luxury properties to buyers on the beach. This has also restructured the real estate market. Many residents had moved out of the city by 2014 , because life had become almost unbearable compared to previous periods. Rents increased by 25 percent between 2000 and 2016 .

In response to the issues raised, the Chamber of Commerce, tourism professionals and the City government considered how solutions could be found to this situation, knowing that overcrowding had placed a heavy burden on protected areas, World Heritage sites, the coast, the old town center and its main artery, La Rambla, which leads to the coast. A legitimate question arose as to what mass tourism had brought about in the city, but also what effect tourism regulations might have had.

The local residents have had issues with the growing number of visitors since 2000 . They especially oppose travel by younger visitors who are believed to have done the most damage to the city. However, residents are still willing to host tourists, preferably those who are respectful of the values of the city and the quality of life.

Since 2014, there have been several major protests against the proliferation of tourism. Protesters threw paint bombs at several hotels, attacked buses and anti-tourist graffiti and posters appeared. In one demonstration, for example, city dwellers chanted „drunk tourists go home”, but there were also examples of protesters stopping tourist buses. The graffiti artists of the region did not hide their views: „tourists, go home” and ,tourism kills" inscriptions appeared in more and more places. The worst case of vandalism was when the tires of a tourist bus were punctured and the windows were covered with paint, but other tourist vehicles and bicycles had also been attacked (BARCELONA ANTI-TOURISM ACTIVISTS VANDALISE BIKES AND BUS 2017; EURÓPA LEGNÉPSZERÜBB VÁROSAIBAN A HELYIEK LÁZADOZNAK A TURISTÁK ELLEN 2017; MEGFOJTJA ÖKET A TURIZMUS 2019).

To prevent further violent protests, the city administration has taken concrete measures to reduce, or at least not increase the number of visitors.

Visiting traffic has been banned or restricted in some places and as a result, the concentration of visitor traffic in the vicinity of the central attractions has eased. Barcelona has been thinking about reducing the impact of mass tourism since 2013. In the case of Güell Park, the new restrictions allowed 400 visitors to stay in the park per hour, compared to the previous 3,000 visitors. 
In 2013, the previously free park now requires paid admission to reduce the number of visitors, however it remains free for Barcelona residents with capacity restrictions: 100 Barcelona residents could visit the park every hour for free. An online ticketing system was also introduced at the city's most popular attraction, the Sagrada Familia, which determined how many people can visit at a time and for how long. The latter was strictly controlled (BALLESTER, P. 2018; DÖNTÖTTEK A TURIZMUS KORLÁTOZÁSÁRÓL BARCELONÁBAN 2017; MEGFOJTJA ÖKET A TURIZMUS 2019).

The construction of larger hotel complexes was prohibited and the legal framework for apartment rental was tightened. Regulations affecting Airbnb were first adopted in 2015, because it provided apartment accommodations that competed with hotels. Under the new rules, individuals could rent up to two bedrooms for up to 4 months. The current mayor also won the election with the slogan "Give the city back to its citizens". He also kept his word, revoking the licenses of 30 hotel projects, obliging Airbnb to pay $€ 600,000$, and private landlords were required to obtain licenses. The reality, however, was that prior to the pandemic, approximately 140,000 advertisements were posted on rental platforms each year and control of such rental units was ineffective. In 2017, another law came into force to curb tourism, such that, it became impossible to open new hotels or rent new apartments in the city center. If an existing hotel or apartment was closed, there new hotels or new apartments could not built. Further investigation was conducted into unreported accommodations (BALLESTER 2018).

\section{Conclusions}

In the study, I explored the interpretation of sustainable tourism through literature reviews and analyzed the documents that made recommendations on this topic. The common denominator of these documents is that the three pillars of sustainable development are the environment, the economy, and society, and in this interaction the economy can only grow together with the protection of the environment. Thus, quantitative and qualitative growth are only viable together. Sustainable tourism appears in the literature as the opposite of overtourism also called mass tourism, which has negative impatcs. Sustainable tourism satisfies the needs of tourists, protects the natural and cultural environment, and seeks to increase the economic benefits of tourism and involves the local population in development processes.

Prior to the coronavirus pandemic, several European cities were struggling with overtourism. Unfortunately, few countries have government programs for the management and administration of tourism. Overtourism means an excessive increase in the number of visitors in a given location, which results in overloading the local infrastructure and limiting access to services for the population. At the same time, the leaders of the destinations have to recognize the need to limit the growth of tourism and take steps towards sustainable tourism, for example to ensure that the level of traffic and the distribution of visitors correspond to the capacity of the destination. Many good examples of tackling the overtourism phenomenon have emerged in recent years, but some of these also seemed to be more ad hoc solutions, ignoring disciplined planning and the sustainable tourism principles.

The overtourism phenomenon was abated by the global coronavirus pandemic, which caused a drastic decline in tourist traffic. In order to rebuild the tourism sector, the European Commission has initiated the development of a European „Marshall Plan” to finance the recovery of the travel and tourism sector.

The case study of Barcelona also confirmed that before the pandemic, the city was struggling with the phenomenon of overtourism and if left unresolved, the situation would yield unpredictable consequences in the lives of local residents. Since the 1992 Olympic Games, growing tourism has transformed the housing market and significantly changed the old cityscape. For several years now, citizens have been regularly demonstrating against tourists and demanding that the city find solutions to the problems caused by tourists. 
As a result, the city government has taken concrete measures to reduce, or at least not increase the number of tourists. Examples of these measures include restricting visitor traffic, revoking hotel licenses, and regulating Airbnb and other home rental platforms.

However, the pandemic substantially reduced the volume of tourists in Barcelona. Overtourism was replaced by a lack of tourists (KLIGER 2020). Normally, there are serpentine lines at the Sagrada Familia, the city's most popular attraction, but since 13 March 2020, the iconic building has been completely empty. Visits to Casa Milá also fell 65 percent because of the pandemic. However, this period may provide an opportunity for more conscious tourism planning than before, in preparation for a return to pre-coronavirus visitor traffic.

\section{References}

BALLESTER, P. (2018): Barcelona and Mass Tourism: Tourismophobia and Coexistence. Barcelona. Retrieved from: https://www.academia.edu/37004609/Barcelona_And_Mass_Tourism_Overtourism_Tourismoph obia_and_Coexistence Last visit: 02.06.2020.

BURTON, R. (1995): Travel Geography. Longman, Harlow-London. CLAUDIO, M. - JOSEPH, M. C. - MARINA, N. (2018): Overtourism: a growing global problem. The Conversation. Retrieved from:

https://www.researchgate.net/publication/326573468_Overtourism_a_growing_global_problem Last visit: 02.06.2020.

DIAZ, A. 2020. Tourist numbers in Barcelona's hotels 1990-2019. Statista, Travel, Tourism and Hospitality, Leisure Travel. Retrived from: https://www.statista.com/statistics/452060/number-oftourists-in-barcelona-spain/\#statisticContainer Last visit: 24.03.2021.

DÁVID, L. - BAROS, Z. (2007): A Possible Use of Indicators for Sustainable Development in Tourism. An International Journal of Tourism and Hospitality Research, 18(2): pp. 349-355. DOI: 10.1080/13032917.2007.9687211

DÁVID L. - SZÜCS CS. (2008): Environmentalism in tourism: the connection of lifestyle, tourism and sustainable tourism. Gazdálkodás: Agrárökonómiai tudományos folyóirat különszám Szerdahelyi P. (szerk.) 52(22): pp. 65-75. DOI: 10.22004/ag.econ.48092

ECM (2020): The DMMO COVID-19 Continuity Checklist. An ECM Guide for Sustainable Recovery. Retrived from: https://www.europeancitiesmarketing.com/webinar-continuitychecklist/ Last visit: 02.06.2020.

HOLDEN, A. (2016): Environment and Tourism. Routledge, London and NY. DOI: doi.org/10.1002/jtr.339

KLIGER, I. (2020): Barcelona goes from overtourism to no tourism. Retrived from: https://www.nationalgeographic.com/travel/2020/04/coronavirus-barcelona-goes-from-

overtourism-to-no-tourism/ Last visit: 04.06.2020.

KRIPPENDORF, J. (1987): The holiday makers: understanding the impact of leisure and travel.

Oxford.

LENGYEL, M. (2004): A turizmus általános elmélete. Heller Farkas Gazdasági és Turisztikai Szolgáltatások Főiskolája, Budapest.

MEGAN, E. W. (2020): A Marshall Plan for Tourism. Can it be built? Retrived from: http://www.eplerwoodinternational.com/marshall-plan-fund-reports/ Last visit: 05.06.2020.

MICHALKÓ, G. (2003): A fenntartható fejlődés ökoturisztikai aspektusai Magyarországon. Turizmus Bulletin 7(4): pp. 13-21.

MOWFORTH, M - MUNT, I. (1998): Tourism and Sustainability. New Tourism in the Third World. Routhledge, London. Retrived from: https://kelasparhiugm2016.files.wordpress.com/2016/03/martin-mowforth_-ian-munt-tourismand-sustainability-_-development-and-new-tourism-in-the-third-world-routledge-2003.pdf Last visit: 08.06.2020. 
PUCZKÓ L. - RÁTZ T. (2005): A turizmus hatásai. Aula Kiadó, Budapest.

QUEBEC-I NYILATKOZAT AZ ÖKOTURIZMUSRÓL (2002): Turizmus Bulletin 6(4): pp. $13-$ 17. Retrived from: https://mtu.gov.hu/documents/prod/Turizmus-Bulletin-VI.-evfolyam-4.szamOKO.html Last visit: 09.06.2020.

TASNÁDI J. (2002): A turizmus rendszere. Aula Kiadó Kft., Budapest.

UNWTO (2019): World Tourism Barometer 17(1). Madrid. Retrived from: https://www.eunwto.org/doi/epdf/10.18111/wtobarometereng.2019.17.1.1 Last visit: 10.06.2020.

UNWTO (2018): Overtourism: Understanding and managing urban tourism beyond perceptions. Executive summary. Madrid. Retrived from: https://www.eunwto.org/doi/pdf/10.18111/9789284420070 Last visit: 10.06.2020.

UNWTO (2002): Global code of ethics for tourism. Contributions of the World Tourism Organization to the World Summit on Sustainable Development. WTO, Johannesburg: WTO. 3050 .

UNWTO (2001): Osaka Millennium Declaration. Retrived from: https://www.eunwto.org/doi/pdf/10.18111/unwtogad.2001.1.v385u76984x63188 Last visit: 10.06.2020.

UNWTO (1999): Global Code of Ethics for Tourism. Madrid. Retrived from: https://www.unwto.org/global-code-of-ethics-for-tourism Last visit: 11.06.2020.

UNWTO (2000): A fenntartható turizmus fejlesztése. Irányelvek a turizmus tervezöinek és szervezöinek/közread. Geomédia Kiadó, Budapest - WTO.

UNWTO - WTTC - EC (1995): Agenda for the Travel and Tourism Industry: Towards Environmentally Sustainable Development. WTTC, Budapest.

UNWTO - IPU (1989): Hágai Nyilatkozat. Idegenforgalmi Közlemények 4: pp. 3-6.

UNWTO (1980): Manila Declaration on World Tourism. Madrid. Retrived from: https://www.univeur.org/cuebc/downloads/PDF\%20carte/65.\%20Manila.PDF Last visit: 10.06.2020.

\section{Internet sources:}

Barcelona anti-tourism activists vandalise bikes and bus (2017). Retrieved from: https://www.theguardian.com/world/2017/aug/01/barcelona-anti-tourismactivists-vandalise-bikes-and-bus. 1/08/2017 Last visit: 11.06.2020.

Döntöttek a turizmus korlátozásáról Barcelonában (2017). Retrieved from:

https://www.travelo.hu/tavol/20170127-barcelona.html 26/01/2017. Last visit: 15.06.2020.

Európa legnépszerübb városaiban a helyiek lázadoznak a turisták ellen (2017).

Retrieved from: https://www.travelo.hu/tavol/20170815-ahol-a-helyiek-nem-orulnek-a turistaknak.html 2017. augusztus 15. Last visit: 15.06.2020.

International year of sustainable tourism for development (2017). Retrieved from: http://www.tourism4development2017.org/about/ Last visit: 15.06.2020.

Megfojtja őket a turizmus (2019). Élmény \& Világ. City, Világ. Retrieved from:

http://www.elmenyvilag.com/2019/01/01/megfojtja-oket-a-turizmus/ 2019.01.01. Last visit: 15.06.2020. 